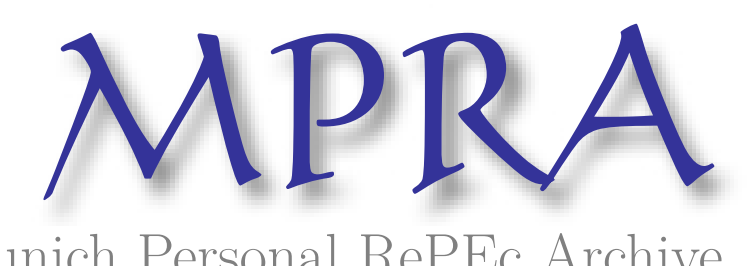

Munich Personal RePEc Archive

\title{
Assessing the Impact of a GET Surcharge on Hawaii's Economy: A Response to Testimony from the Department of Budget and Finance on SB 727
}

Liou, Wayne and Nitz, Lawrence H.

12 August 2015

Online at https://mpra.ub.uni-muenchen.de/68776/

MPRA Paper No. 68776, posted 13 Jan 2016 19:53 UTC 


\title{
Long-Term Services \&
}

\section{Supports Feasibility Policy Note}

\section{Assessing the Impact of a GET Surcharge on Hawai'i's Economy: A Response to Testimony from the Department of Budget and Finance on SB 727}

\author{
Wayne Liou, M.A., and Lawrence H. Nitz, Ph.D. \\ August 12, 2015
}

Science has led to people living longer and longer. However, despite science's ability to extend peoples' lifespans, health problems in old age have not been eliminated. This aging of the population requires a careful consideration on the funding and delivery of long-term care. At the moment, Hawai' $i$ is incapable of financing, organizing, and delivering quality long-term care for a majority of the population, in part due to the high cost of long-term care. Most people do not have private long-term care coverage; few people can afford private long-term care insurance, and private health insurance does not cover long-term care. Meanwhile, public sources of funding either do not cover long-term care (Medicare) or do not provide enough important services such as home and community-based services (Medicaid QUEST Expanded Access).

To address this problem, the Long-Term Care Commission was established following Act 224, Session Laws of Hawai'i 2008. The purpose of this Commission was to conduct a comprehensive assessment of Hawai'i's long-term care system and to recommend changes. The Commission's final report ${ }^{1}$, released in 2012, offered some recommendations; this was followed by a house bill funding a feasibility study for a mandatory limited term, limited benefit social insurance program. HB1SD2, passed during the 2013 legislative session, asked twenty specific questions with regards to the feasibility of such a social insurance program, including the method for collecting premiums.

The Long-Term Services and Supports Social Insurance Program feasibility report ${ }^{2}$ offered a variety of proposals - a flat premium, an income tax surcharge, and a general excise tax surcharge. A formal bill, SB 727 SD1 $^{3}$, was proposed to the Twenty-Eighth legislature, with a surcharge on Hawai'i's General

\footnotetext{
${ }^{1}$ http://www.publicpolicycenter.hawaii.edu/projects-programs/ long-term-care/HawaiiLTCCFinalReport.pdf

2 http://www.hawaiiadrc.org/Portals/ AgencySite/LTSS/LTSS 2.pdf

3 http://www.capitol.hawaii.gov/session2015/Bills/SB727 SD1 .PDF
} 
Excise Tax as the revenue source. Testimony on the bill showed concern with impact of an increase to the general excise tax on the economy. This report is a response to the concern of the economic impacts of an increase to the general excise tax.

Is it possible to estimate how a half percent increase in the general excise tax would affect the state's economy? Fortunately, a recent tax increase for transactions on O'ahu allows for such an analysis. By comparing tax revenue on $\mathrm{O}^{\prime}$ ahu with tax revenue on Neighbor Islands, some insight into the effects of a half percent increase in the general excise tax can be gained.

\section{A One-Half Percent GET Surcharge: the City \& County of Honolulu "Rail Tax"}

In May 2004, the Hawai'i State Legislature passed a bill that would allow counties to impose a one-half percent increase in the Hawai'i General Excise Tax (GET) on goods and services charged at the 4\% GET rate. These taxes would be used to fund general public transportation infrastructure in the entire state, with an emphasis on funding Mayor Mufi Hannemann's rail proposal. The bill was enacted as Act 247 on July 12, 2005, Mayor Hannemann signed into law the authorizing of the one-half percent GET increase on August 24, and the increase went into effect on January 1, 2007. The funds raised from this one-half percent increase on O'ahu could only be used for the construction and operation of a mass transit system.

\section{Analysis}

If all the counties authorized this one-half percent increase to the excise tax, the current analysis would not be straightforward, as it would not be possible to compare counties affected by an increase in tax and counties unaffected by the tax increase. However, with the Neighbor Islands choosing to not implement the increase in the GET, the analysis is made much easier. O'ahu's tax revenue before and after the one-half percent increase can be compared to Maui, Kauai, and Hawai'i Counties' tax revenue to determine if the increase had an impact on the economy.

Hawai'i's General Excise Tax (GET) is a tax imposed on businesses' gross income. Thus, every business transaction in Hawai'i results in some tax revenue received by the state. People who have made a purchase in Hawai'i will sometimes see a tax show up on sales receipts, but this is not an additional sales tax. Rather, the state allows businesses to add the tax to purchases, making customers pay the

GET more directly. Businesses must pay the GET every month, three months, or six months, depending on how much excise tax paid by the business. The tax form filed by businesses divides a business's different sources of income, and depending on the source, gets charged either $4 \%, 0.5 \%$, or $0.15 \%$. Income from retailing; services; contracting; theater, amusement, and broadcasting; commissions; transient accommodations (hotel) rentals; other rentals; interest; and imports for consumption are taxed at 4\%. Income from wholesaling, manufacturing, producing, wholesale services, imports for resale, and business activities of disabled persons are taxed at $0.5 \%$. Income from insurance commissions is taxed at $0.15 \%$.

The City and County of Honolulu surcharge of $0.5 \%$ is charged on all O'ahu business transactions taxed at the $4 \%$ rate, regardless of where the business is registered. Thus, businesses registered in Maui County, Kaua'i County, and Hawai'i County occasionally pay the City and County of Honolulu surcharge, 
but this never exceeds $0.6 \%$ of a county's total tax revenue, compared to an average of $4 \%$ of total tax revenues for the City and County of Honolulu.

Multiple comparisons can be made from these differences in which transactions have the City and County of Honolulu surcharge. This is particularly useful, with the implementation of the surcharge occurring around the time of the Great Recession. Without any comparisons, a dip in tax revenue could be a symptom of the additional $0.5 \%$ tax or a downturn in the economy from the recession. Likewise, any recovery from the recession could mask effects of the surcharge.

The different sources of income on O'ahu can be compared, but the businesses heavily involved in wholesaling, manufacturing, producing, etc. might react very differently to a recession/recovery than the retailing, services, contracting, and rental businesses. Tax revenues from the incomes sources charged at the $4 \%$ rate can be compared across the counties, looking at O'ahu's tax revenue from retailing, services, contracting, etc. and the tax revenue from these sources from the Neighbor Islands. This might pose some problems again, however, as the islands might have been affected by the recession differently. To address this, the tax revenues from the income sources taxed at the $0.5 \%$ rate can be compared across the islands to determine if the recession affected the islands differentially. If tax revenue is similar across the islands before and after the recession, comparing the Neighbor Island's tax revenue from retailing, services, contracting, etc. to O'ahu's with the assumption that the islands were similarly affected by the recession is perhaps more believable.

\section{Figure 1}
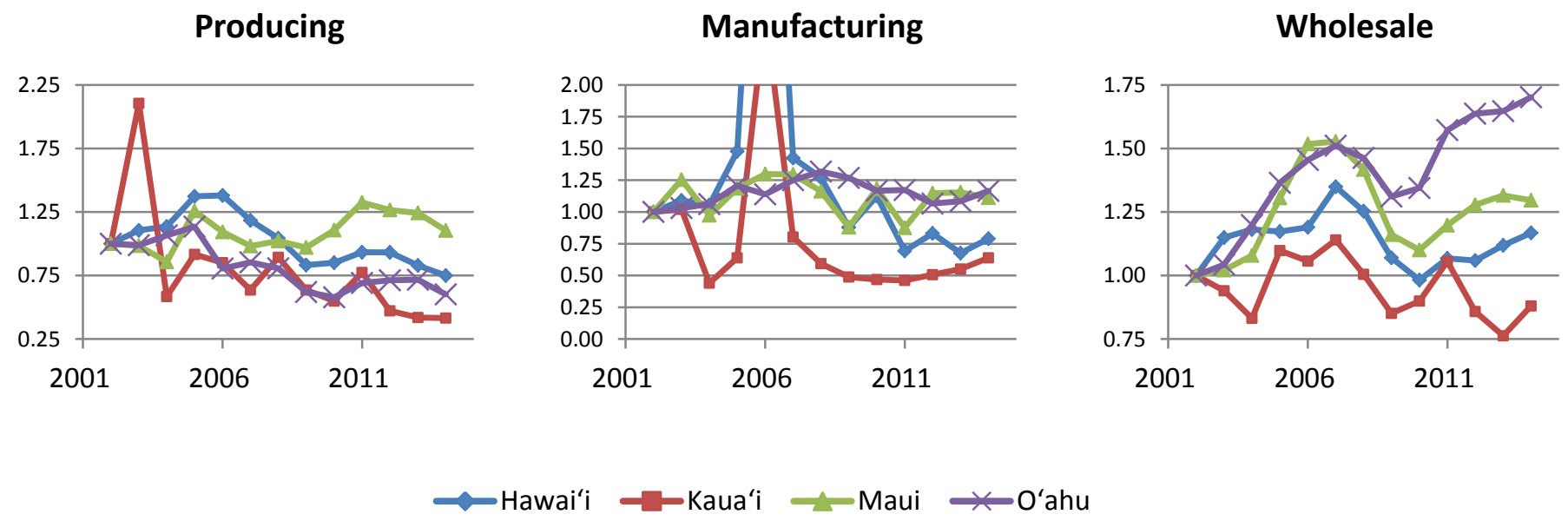

To perform this analysis, GET data from all counties was collected for 2002-2014 from the Monthly Tax Collection Reports on the Hawai'i State Department of Taxation website ${ }^{4}$. Even though the General Excise Tax form that businesses fill out and return to the Department of Taxation includes a section to calculate the City and County of Honolulu surcharge, the revenue gained from the surcharge is not included in these values. To facilitate the comparisons, the taxes were normalized by the 2002 tax

\footnotetext{
${ }^{4}$ 2010-2014: http://tax.hawaii.gov/stats/a5 3txcolrpt/; 2002-2009: http://tax.hawaii.gov/stats/a5 3txcolrptarchive2009/
} 
revenue for each county-income source. In this manner the comparison focuses on how much revenues have changed relative to 2002 in a particular county from a particular income source.

From the three primary categories that are charged at the $0.5 \%$ tax rate, it appears that the $\mathrm{O}^{\prime}$ ahu did not face a particularly unique recession. Though revenue from wholesale transactions in $\mathrm{O}^{\prime}$ ahu are typically higher than the Neighbor Islands, it exhibits similar growth pre-recession, downturn between 2007-2009, and recovery afterwards. Meanwhile, production and manufacturing in O'ahu face very similar patterns with the Neighbor Islands. In fact, O'ahu is arguably more negatively affected by the recession in the "producing" category. This suggests that the recession affected all the counties in a rather similar fashion.

As further evidence of the consistent impact of the recession across the islands, data from the tourism industry can be examined for possible differences between the islands. The tourism industry is probably the key industry to examine for differential impacts of the recession among the islands, as tourism is a major contributor to the state's GDP and is sensitive to economic downturns. Data on visitor statistics from 2004-2012 was pulled from the Monthly Visitor Statistics on the Hawaiian Tourism Association website ${ }^{5}$. Two visitor statistics stand out as the most useful to analyze: visitor days by county and visitor expenditures by county. "Visitor days" is a little higher on O'ahu between 2004-2005, but otherwise, the pattern in visitor days is as similar across islands as one can get.

Likewise, visitor expenditure is rather comparable, particularly from 2008-2011. As visitors are unlikely to know about the surcharge on O'ahu and probably are not affected by the extra $0.5 \%$ tax on their purchases, this is evidence that the analysis of the $4 \%$ tax rate categories across islands is safe from contamination from the recession.

\section{Figure 2}

Visitor Days

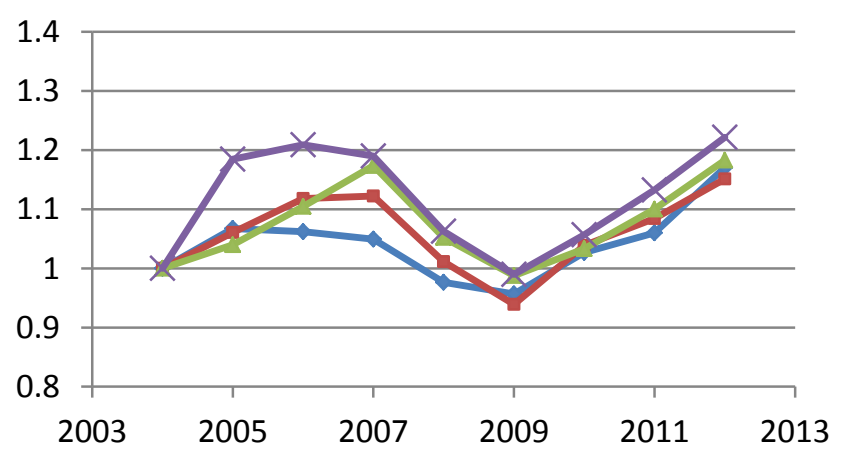

Visitor Expenditure

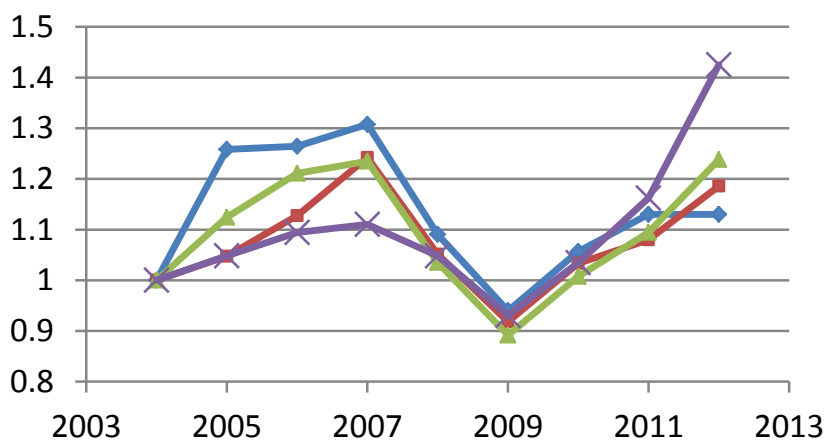

$$
\leadsto \text { Hawai'i Kaua'i Maui } \longleftarrow \text { O’ahu }
$$

\footnotetext{
${ }^{5}$ http://www.hawaiitourismauthority.org/research/research/visitor-highlights/
} 


\section{Figure 3}

Retailing

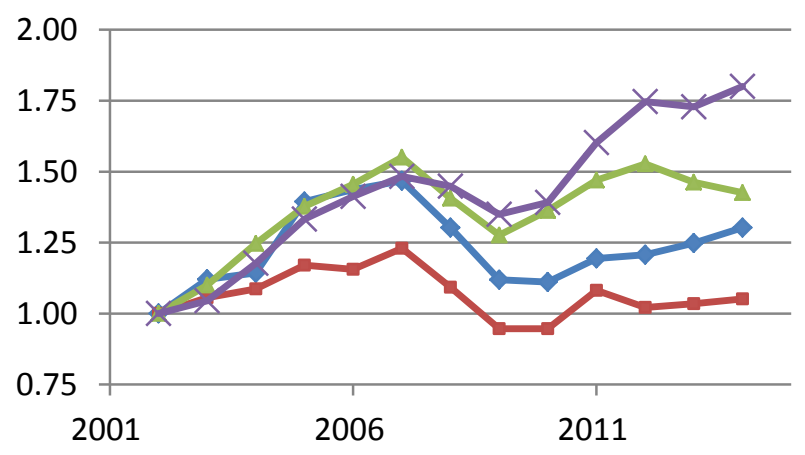

Contracting

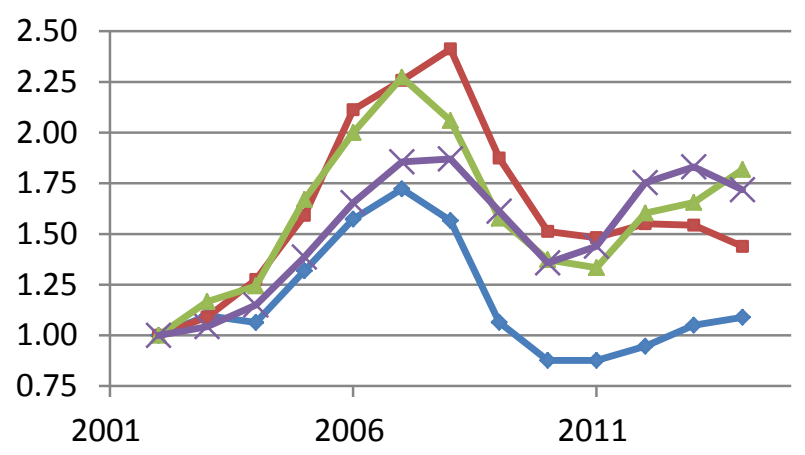

4\% GET Total

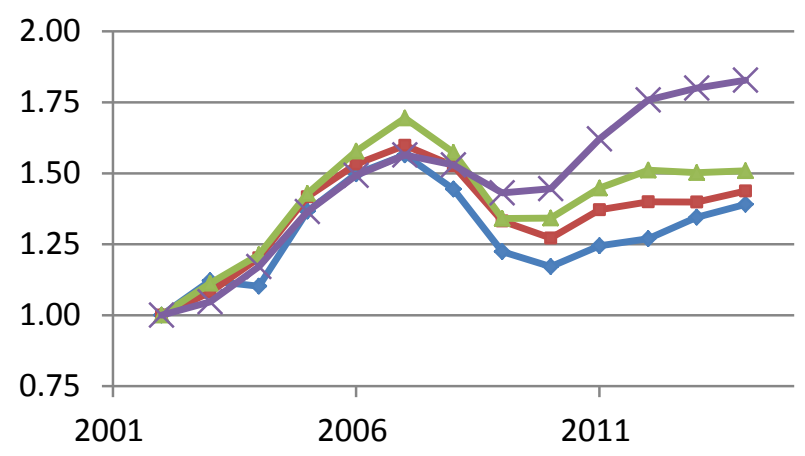

\section{Services}

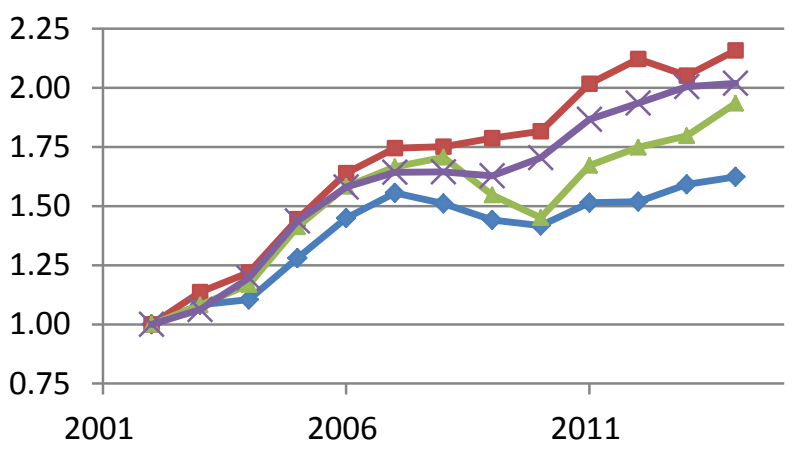

Hotel Rentals

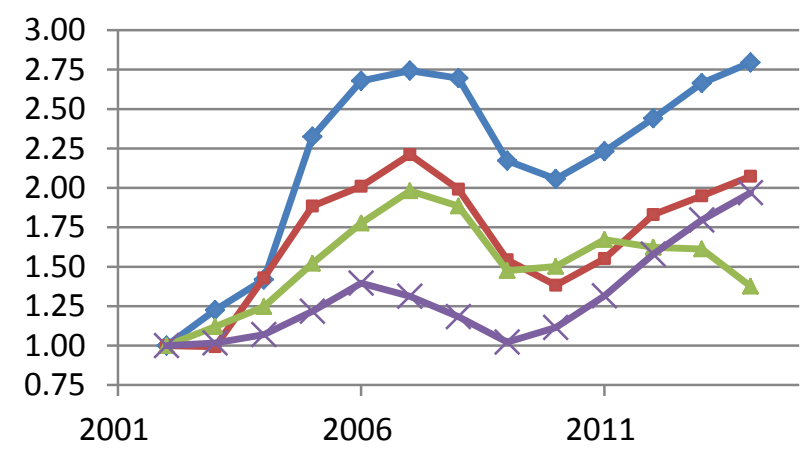

All GET Total

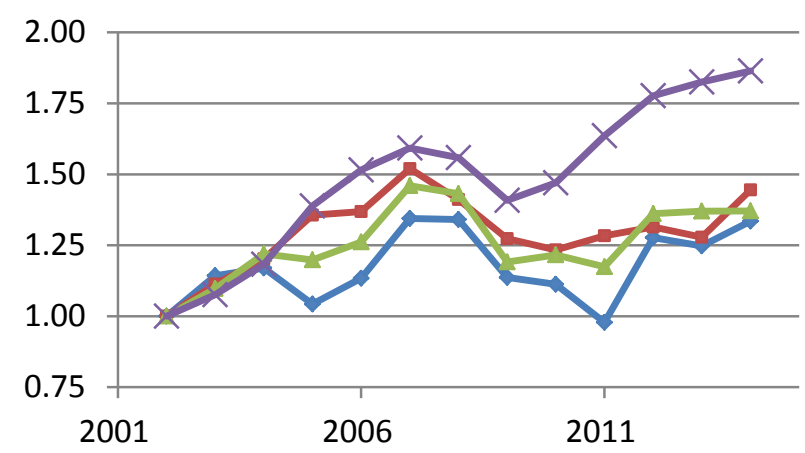


Focusing on the three major contributors to the $4 \%$ GET, O'ahu is not significantly different from the other counties. Hawai'i County's contracting sector has a poor reaction to the recession, but this is the only county-income source that stands out in particular. Hotel rentals are another large contribution to tax revenues for the $4 \% \mathrm{GET}$, and since they are primarily driven by tourists instead of locals, they are of use in considering the effects of the surcharge and the recession. As the post-2007 shape of the graph for each county's revenue from hotel rentals is very similar, it would appear that neither the recession or the City and County of Honolulu surcharge had a unique impact on O'ahu. The graphs for the sub-total for the income sources taxed at the $4 \%$ rate and the total General Excise Tax show no evidence that the City and County of Honolulu surcharge has a large, detrimental effect on O'ahu's economy with regards to business transactions.

As a brief aside, the funds from the surcharge was injected into O'ahu's economy in 2011, with the ground-breaking for the Honolulu Rail Transit Project on February 22, 2011. The graph for the 4\% GET Total and All GET Total looks like there might be a slight acceleration in growth after 2010 in O'ahu compared to the other counties, suggesting that even though the surcharge had minimal impact on the economy, the government spending from this revenue in fact boosted the economy. The source of this growth, however, is primarily from retailing and wholesale, not necessarily sectors that would benefit directly from the spending for the Honolulu Rail Transit Project - contracting on O'ahu after 2010 is not unique among the four counties.

An argument could be made that even though the GET was unaffected by the surcharge, the economy could have still been affected. To analyze whether this was the case, all tax revenue received by the State of Hawai'i Department of Taxation was compared across islands. If people did not change their consumption behavior, as the previous analysis on the GET revenue suggests, how else might have people been affected? The most obvious answer is probably income; perhaps businesses adjusted prices and wages in conjunction that resulted in the lack of evidence for the surcharge having an effect.

Revenue from income tax, however, shows little differentiation among the different counties. Even though Kaua'i shows some high collection of income tax from 2005-2008 relative to the other counties, the pattern is pretty similar across the counties. O'ahu's growth in income tax after 2009 is flatter than the Neighbor Islands', but is similar to the growth in income tax between 2001-2007, a pattern the other counties have (growth in income tax from 2009-2014 being similar to growth in income tax rate from 2001-2007). Looking at all tax revenue earned by county less the City and County of Honolulu surcharge, and there is still little evidence of a negative impact of the surcharge. In fact, much like the 4\% GET Total and the All GET Total graph, O'ahu outpaces the other islands after 2008. 


\section{Figure 4}
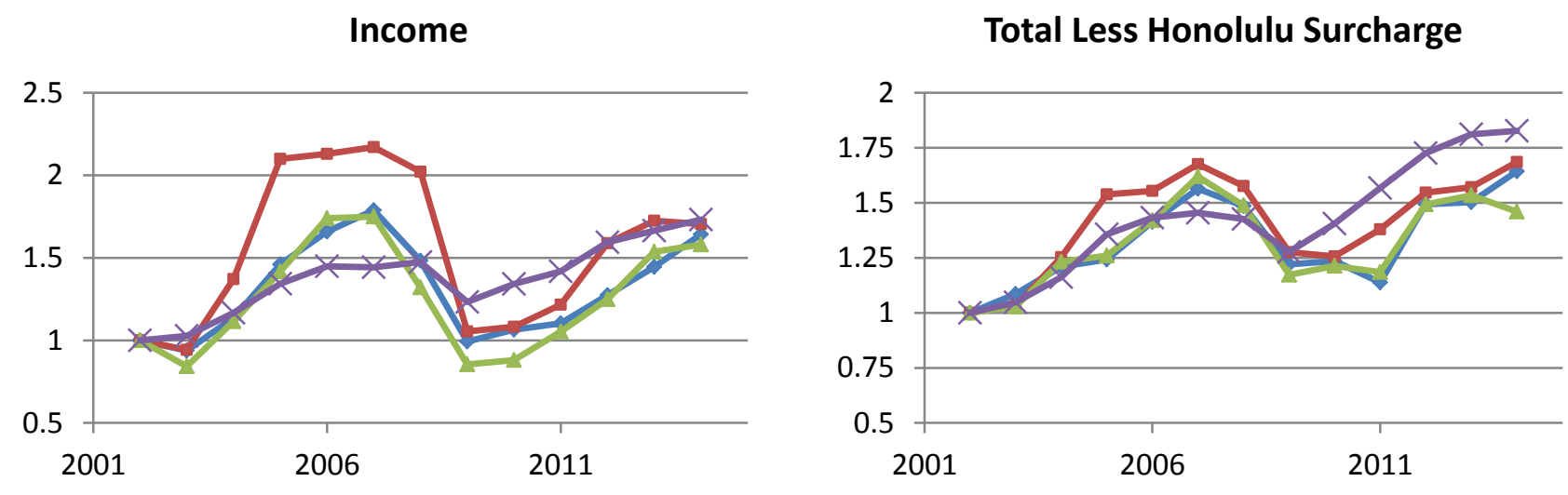

$$
\leadsto \text { Hawai'i } \longleftarrow \text { Kaua'i Maui } \longleftarrow \mathrm{O}^{\prime a h u}
$$

\section{Conclusion}

A solution to the lack of affordable long-term care has been proposed in Hawai'i. A long-term care surcharge on the state's General Excise Tax could fund a long-term care financing program. Concern over the potential impact of a GET surcharge was expressed, and this report demonstrated that such a surcharge will likely have a minimal effect on the economy. After looking at a previous, similarly sized surcharge that only applied to certain transactions on O'ahu, and comparing tax revenue of all the islands after the enactment of the City and County of Honolulu surcharge, this report found no evidence that a $0.5 \%$ surcharge on Hawai'i's GET having a large, negative impact on the economy. 